\title{
Effect of two microbial phytase preparations on phosphorus utilisation in broilers fed maize-soybean meal based diets
}

\author{
Jarmo Valaja, Sini Perttilä, Kirsi Partanen, Tuomo Kiiskinen \\ Agricultural Research Centre of Finland, Animal Production Research, Animal Nutrition, \\ FIN-31600 Jokioinen, Finland, e-mail: jarmo.valaja@mtt.fi \\ Jari Piironen \\ Röhm Enzyme Finland Ltd, FIN-05200 Rajamäki, Finland
}

\begin{abstract}
The present study was carried out to determine the effect of two microbial phytases, Aspergillus niger (FINASE ${ }^{\circledR}$ FP-500, 291 PU (phytase units)/g) and Trichoderma reesei phytase (FINASE ${ }^{\circledR}$ P, $^{2}$ $5880 \mathrm{PU} / \mathrm{g}$ ) on phosphorus (P) and calcium (Ca) utilisation and ileal $\mathrm{P}$ and Ca digestibility in broiler chickens fed diets based on maize and soybean meal. A total of 96 Ross broiler chickens housed four birds to a cage were used. Four dietary treatments consisted of a positive control supplemented with dicalcium phosphate (17 g/kg), a negative control without inorganic P, basal diet without inorganic $\mathrm{P}$ supplemented with Aspergillus niger phytase $(2.6 \mathrm{~g} / \mathrm{kg})$ and basal diet without inorganic P supplemented with Trichoderma reesei phytase $(0.13 \mathrm{~g} / \mathrm{kg})$. Both phytases provided $750 \mathrm{PU} / \mathrm{kg}$ feed. $\mathrm{P}$ retention per unit intake was lowest and $\mathrm{P}$ excretion highest in birds fed the positive control diet with inorganic $\mathrm{P}(\mathrm{P}<0.001)$. Both phytases clearly decreased $\mathrm{P}$ excretion $(\mathrm{P}<0.05)$ and increased $\mathrm{P}$ utilisation $(\mathrm{P}<0.001)$ compared to the negative control treatment. No differences were found between Aspergillus and Trichoderma phytases in P retention. Phytase supplementations also increased apparent ileal digestibility of $\mathrm{P}$ compared to the negative control treatment $(\mathrm{P}<0.05)$. Phytase supplementation also increased $\mathrm{Ca}$ retention per unit intake $(\mathrm{P}<0.001)$. In conclusion, both microbial phytases were equally effective in improving utilisation of $\mathrm{P}$ in broiler chickens fed maize-soybean meal diets.
\end{abstract}

Key words: Aspergillus niger, enzymes, digestibility, minerals, poultry, Trichoderma reesei

\section{Introduction}

In cereals and vegetable protein sources between half to three quarters of phosphorus $(\mathrm{P})$ is bound to phytic acid (Eeckhout and De Paepe 1994) and has therefore, only limited availability in poultry (Nelson et al. 1968, Simons et al. 1990, Kiiskinen et al. 1994). Phytic acid does not only limit the utilisation of plant $P$, but also complexes with various cations, e.g. calcium and protein, reducing their availability (Ravindran et al. 1999).

\section{(C) Agricultural and Food Science in Finland} Manuscript received November 2000 


\title{
AGRICULTURAL AND FOOD SCIENCE IN FINLAND
}

\author{
Valaja, J. et al. Effect of two microbial phytases on P utilisation in broilers
}

Because of growing concern about environmental pollution, attempts have been made to reduce $\mathrm{P}$ output from broiler production. It has been demonstrated that microbial phytase is effective in releasing a significant proportion of the phytate $\mathrm{P}$ present in maize and soybean meal (Nelson et al. 1968, Simons et al. 1990). Microbial phytase has enhanced $\mathrm{P}$ utilisation of maizesoybean meal diets in broilers and reduced the amount of P in excreta (Simons et al. 1990, Broz et al. 1994, Kornegay et al. 1996).

Phytase from Aspergillus niger and Trichoderma reese $i$ has been equally effective in improving the digestibility of $\mathrm{P}$ in maize and soybean meal diet in pigs (Näsi et al. 1999). Aspergillus niger phytase has been shown to improve $\mathrm{P}$ utilisation in broilers (Broz et al. 1994, Kiiskinen et al. 1994), but so far little is known about the efficacy of Trichoderma reesei phytase in broiler diets. Therefore, the current study was carried out to determine the effects of two microbial phytases, Aspergillus niger (FINASE ${ }^{\circledR}$ FP500) and Trichoderma reesei (FINASE ${ }^{\circledR} \mathrm{P}$ ) on $\mathrm{P}$ and calcium $(\mathrm{Ca})$ utilisation in broilers fed maize-soybean meal based diets.

\section{Material and methods}

\section{Animals and experimental procedures}

A digestibility and balance experiment was conducted with 96 Ross broiler chickens between 21 and 37 days old. One-day old broiler chicks were sexed, marked with numbered wing marks and placed in 3-floor battery wire cages (size $47.5 \times 56 \times 40 \mathrm{~cm}$ ), four birds (two males and two females) in each cage. Four cages were treated as one experimental block, within which one cage was randomly allocated each treatment. Treatments were evaluated with six replicate cages. The experiment was conducted as a randomised block design with four experimental treatments: 1. maize-soybean meal diet supplemented with dicalcium phosphate (positive con- trol), 2. maize-soybean meal diet without inorganic P supplementation (negative control), 3. maize-soybean meal diet without inorganic $\mathrm{P}$ supplemented with Aspergillus niger phytase (750 PU (phytase units)/kg feed) and 4. maizesoybean meal diet with inorganic P supplemented with Trichoderma reesei phytase (750 PU/kg feed).

The duration of the trial was 17 days. Birds were fed for the first three weeks a standard starter diet (200 g crude protein/kg diet) and experimental diets were introduced at age of 21 days. After a 7-day adaptation period, a total excreta collection was conducted during four days. Excreta of birds were collected from trays under cages once a day and placed into a freezer $\left(-20^{\circ} \mathrm{C}\right)$ prior to analysis. A second adaptation period lasted five days. Before the collection of digesta at the age of 37 days, birds were fasted for 24 hours. After fasting birds had free access to feed for four hours one block at a time. Samples of ileal content were taken from the birds after stunning and neck dislocation one block at a time, with a time interval between blocks of 45 minutes. The small intestine was removed and ileal digesta were sampled from distal half between the Meckels diverticulum and ileo-caecocolic junction. Samples of four birds from the same cage were pooled. Digesta samples were placed into a freezer $\left(-20^{\circ} \mathrm{C}\right)$ immediately after collection. Animals were weighed at the beginning and at the end of the trial and at the beginning of the collection period and the second adaptation period. Feed intake of each cage was recorded during the collection period and after fasting. Temperature was maintained at $+22^{\circ} \mathrm{C}$ and light was controlled according to Ross-broiler breeder instructions (20-h light (5-10 lux) and $4 \mathrm{~h}$ dark cycle). Feed and water were available ad libitum.

\section{Experimental diets}

A maize-soybean meal based diet was formulated to meet the nutrient requirements of broilers except for P (Tuori et al. 1995) (Table 1). A pos- 


\section{AGRICULTURAL AND FOOD SCIENCE IN FINLAND}

Vol. 10 (2001): 19-26.

Table 1. Formulation and analysed chemical composition of experimental diets.

\begin{tabular}{|c|c|c|c|c|}
\hline Treatment & 1 & 2 & 3 & 4 \\
\hline Dicalcium phosphate & + & - & - & - \\
\hline Phytase & - & - & Aspergillus & Trichoderma \\
\hline \multicolumn{5}{|l|}{ Ingredients, $\mathrm{g} / \mathrm{kg}$} \\
\hline Soybean meal & 350.0 & 350.0 & 350.0 & 350.0 \\
\hline Maize & 601.7 & 607.7 & 605.1 & 607.6 \\
\hline Rapeseed oil & 16.0 & 16.0 & 16.0 & 16.0 \\
\hline Limestone & 6.0 & 17.0 & 17.0 & 17.0 \\
\hline Dicalcium phosphate & 17.0 & - & - & - \\
\hline Sodium chloride & 3.0 & 3.0 & 3.0 & 3.0 \\
\hline Vitamin premix $^{1}$ & 2.0 & 2.0 & 2.0 & 2.0 \\
\hline Trace element premix ${ }^{2}$ & 2.0 & 2.0 & 2.0 & 2.0 \\
\hline Cr-mordanted straw & 1.5 & 1.5 & 1.5 & 1.5 \\
\hline Methionine & 0.8 & 0.8 & 0.8 & 0.8 \\
\hline Phytase product ${ }^{3}$ & - & - & 2.6 & 0.13 \\
\hline \multicolumn{5}{|l|}{$\begin{array}{l}\text { Analysed composition } \\
\text { G/kg dry matter }\end{array}$} \\
\hline Dry matter, $\mathrm{g} / \mathrm{kg}$ & 899.7 & 900.5 & 900.2 & 900.9 \\
\hline Organic matter & 947.4 & 952.9 & 953.4 & 952.6 \\
\hline Crude protein & 228.2 & 227.3 & 228.0 & 229.2 \\
\hline Ether extract & 69.7 & 68.1 & 67.7 & 68.9 \\
\hline Crude fibre & 35.9 & 36.8 & 35.7 & 36.8 \\
\hline Ash & 52.6 & 47.1 & 46.6 & 47.4 \\
\hline Lysine $^{4}$ & 11.5 & 11.5 & 11.5 & 11.5 \\
\hline Methionine+cystine ${ }^{4}$ & 8.4 & 8.4 & 8.4 & 8.4 \\
\hline Calcium & 8.3 & 8.0 & 8.3 & 8.2 \\
\hline Total phosphorus & 7.7 & 4.8 & 4.6 & 4.6 \\
\hline Phytate $\mathrm{P}^{4}$ & 2.8 & 2.9 & 2.9 & 2.9 \\
\hline $\mathrm{Ca}$ :P-ratio & 1.1 & 1.7 & 1.8 & 1.8 \\
\hline
\end{tabular}

${ }^{1}$ The vitamin premix supplied the following per $\mathrm{kg}$ diet: $1.4 \mathrm{mg}$ calcium, $5.9 \mathrm{mg}$ phosphorus, $12500 \mathrm{IU}$ vitamin A, $3100 \mathrm{IU}$ vitamin $\mathrm{D}_{3}, 40.0 \mathrm{mg}$ vitamin $\mathrm{E}, 36.0 \mathrm{mg}$ tocopherol, $5.0 \mathrm{mg}$ phylloquinone, $3.0 \mathrm{mg}$ thiamin, $6.0 \mathrm{mg}$ riboflavin, $4.0 \mathrm{mg}$ pyridoxine, $0.03 \mathrm{mg}$ cyanocobalamin, $0.30 \mathrm{mg}$ biotin, $1.0 \mathrm{mg}$ folic acid, $40.0 \mathrm{mg}$ niacin, $15.0 \mathrm{mg}$ pantothenic acid and $0.61 \mathrm{mg}$ antioxidants.

${ }^{2}$ The trace mineral premix supplied the following per kg diet: $0.64 \mathrm{~g}$ calcium, $29.2 \mathrm{mg}$ iron, $5.1 \mathrm{mg}$ copper, $50.3 \mathrm{mg}$ magnesium, $65.1 \mathrm{mg}$ zinc, $0.5 \mathrm{mg}$ iodine and $0.2 \mathrm{mg}$ selenium.

${ }^{3}$ Provided 750 PU/kg diet.

${ }^{4}$ Calculated from table values.

itive control diet was supplemented with dicalcium phosphate. Diets were formulated to contain equal amount of $\mathrm{Ca}$. Phytase preparations were produced by two fungi of Aspergillus niger (FINASE ${ }^{\circledR}$ FP-500, Röhm Enzyme Ltd, Rajamäki, Finland) and Trichoderma reesei (FINASE ${ }^{\circledR}$ P, Röhm Enzyme Ltd, Rajamäki, Finland). Phytases were derived from a mutant strain of Aspergillus niger or from a transgenic organ- ism of Trichoderma reesei (Piddington et al. 1993). Phytase activities were $291 \mathrm{PU} / \mathrm{g}$ and $5880 \mathrm{PU} / \mathrm{g}$ in Aspergillus niger and Trichoderma reesei phytases, respectively. A phytase unit (PU) is defined as the amount of enzyme activity which liberates, under standard conditions $(\mathrm{pH}$ $\left.5.0,37^{\circ} \mathrm{C}\right), 1 \mathrm{nmol}$ of inorganic phosphate from sodium phytate in one minute. Enzyme preparations were premixed with barley starch and add- 


\section{AGRICULTURAL AND FOOD SCIENCE IN FINLAND}

Valaja, J. et al. Effect of two microbial phytases on P utilisation in broilers

ed at 0.26 and $0.013 \%$ inclusion rates to treatments 3 and 4, respectively. Chromium $(\mathrm{Cr})$ mordanted straw $(1.5 \mathrm{~g} / \mathrm{kg})$ was used as an indigestible marker. Diets were mixed and coldpressed (temperature $+55-60^{\circ} \mathrm{C}$ ) as $4 \mathrm{~mm}$ pellets (Amandus Kahl Laborpresse L175) in the feed mill of the Agricultural Research Centre.

\section{Laboratory analysis}

Feed, excreta and ileal digesta samples were freeze-dried and ground through a 1-mm mesh before analysis. Proximate analysis was performed according to standard methods (AOAC 1990). Nitrogen (N) from excreta was determined in fresh samples using the Kjeldahl-technique and that from freeze-dried feeds and ileal digesta samples by the Dumas method using a Leco FP 428 nitrogen analyzer (Leco Corp., St. Joseph, Missouri, USA). Calcium and Cr were determined by atomic absorption spectrometry and total $\mathrm{P}$ was assayed after dry ashing, using the colorimetric vanadate-molybdate based procedure of Tayssky and Shorr (1953). Apparent ileal digestibilities were calculated using $\mathrm{Cr}$ as an indigestible marker. Determination of $\mathrm{P}, \mathrm{Ca}$ and nitrogen retention was calculated based on total excreta collection.

\section{Statistical analysis}

Experimental data were subjected to the analysis of variance using the GLM procedure of SAS (SAS 1990) according to the following model: $y_{i j k l}=\mu+b_{j}+d_{k}+e_{i j k l}$ where $y_{i j k l}$ is the dependent variable, $\mu$ is the overall mean, $b_{j}$ is block effect, $d_{k}$ is diet effect and $e_{i j k l}$ is a normally distributed random variable. Three single degree of freedom orthogonal contrasts were formed to test differences between dietary treatments: $\mathrm{C} 1$ : Basal diet with dicalcium phosphate (positive control) vs. other treatments; C2: Basal diet without additional phosphate (negative control) vs. diets with microbial phytase supplementation;
C3: Aspergillus niger phytase vs. Trichoderma reesei phytase.

\section{Results and discussion}

Two observations were removed from the total excreta collection period due to the presence of blood stains in excreta. Otherwise the birds successfully completed the experiment. Average body weight of the birds was 720 (SE 18.1) and 1499 (SE 41.3) g on days 21 and 37, respectively. During the total excreta collection period, birds on the positive control diet ate more feed than birds fed other treatments $(\mathrm{P}<0.05)$ (Table 2). This is likely to be due to the dilution of the metabolisable energy content of the diet as a result of dicalcium phosphate supplementation. Dry matter intake during the 4 hour period before ileal digestibility assay was 76, 53, 49 and $54 \mathrm{~g}$ for treatments $1,2,3$ and 4 , respectively. Consistent with the total excreta collection period, dry matter intake of birds fed the diet containing dicalcium phosphate was the highest $(\mathrm{P}<0.001)$.

Phosphorus intake and excretion was highest for birds fed the positive control diet $(\mathrm{P}<0.001)$ (Table 2). Phosphorus retention per unit intake clearly increased from $38.5 \%$ to $51.1 \%$ with phytase supplementation $(\mathrm{P}<0.001)$. Phytase supplementation also decreased $\mathrm{P}$ excretion of broilers compared to the negative control diet without inorganic $\mathrm{P}(\mathrm{P}<0.05)$. This is in agreement with previous results of Kornegay et al. (1996), Yi et al. (1996) and Broz et al. (1994) which demonstrated that Aspergillus phytase linearly increased $\mathrm{P}$ retention of maize-soybean meal diets (from 44.3 to $62.6 \%$ ). Kiiskinen et al. (1994) also observed that Aspegillus niger phytase increased the retention of P from $50.9 \%$ to $60.0 \%$ in diets based on wheat, barley and soybean meal. Leske and Coon (1999) determined $\mathrm{P}$ retention responses of different feedstuffs to phytase addition and observed that $\mathrm{P}$ retention of soybean meal and maize was in- 


\section{AGRICULTURAL AND FOOD SCIENCE IN FINLAND}

Vol. 10 (2001): 19-26.

Table 2. Effect of microbial phytases on nutrient retention of nutrients of broilers fed maize-soybean meal based diets.

\begin{tabular}{|c|c|c|c|c|c|c|c|c|}
\hline Treatment & 1 & 2 & 3 & 4 & SEM & \multicolumn{3}{|c|}{ Significance } \\
\hline Dicalcium phosphate & + & - & - & - & & $\mathrm{C} 1$ & $\mathrm{C} 2$ & $\mathrm{C} 3$ \\
\hline Phytase & - & - & Aspergillus & Trichoderma & & & & \\
\hline $\mathrm{n}$ & 6 & 5 & 6 & 5 & & & & \\
\hline Dry matter intake, g/day & 103.8 & 89.7 & 93.7 & 89.2 & 4.95 & $*$ & ns & ns \\
\hline Dry matter excretion, g/day & 29.2 & 25.5 & 25.5 & 24.2 & 1.51 & $*$ & ns & ns \\
\hline $\mathrm{N}$ intake, g/day & 3.79 & 3.26 & 3.42 & 3.27 & 0.180 & $*$ & ns & ns \\
\hline $\mathrm{N}$ excretion, g/day & 1.69 & 1.55 & 1.57 & 1.44 & 0.085 & ns & ns & ns \\
\hline $\mathrm{N}$ retention per intake, $\%$ & 55.5 & 52.8 & 53.9 & 55.9 & 0.69 & ns & $*$ & o \\
\hline Ash intake, g/day & 0.54 & 0.42 & 0.44 & 0.42 & 0.023 & $* * *$ & ns & $\mathrm{ns}$ \\
\hline Ash excretion, g/day & 0.41 & 0.35 & 0.32 & 0.31 & 0.018 & $* *$ & ns & ns \\
\hline Ash retention per intake, $\%$ & 25.7 & 17.5 & 27.3 & 26.9 & 1.01 & ns & $* * *$ & ns \\
\hline Ca intake, g/day & 0.86 & 0.72 & 0.77 & 0.73 & 0.040 & $*$ & ns & $\mathrm{ns}$ \\
\hline Ca excretion, g/day & 0.51 & 0.55 & 0.44 & 0.43 & 0.028 & ns & $*$ & $\mathrm{~ns}$ \\
\hline Ca retention per intake, $\%$ & 41.0 & 24.0 & 42.6 & 40.8 & 1.31 & $* *$ & $* * *$ & ns \\
\hline$P$ intake, g/day & 0.80 & 0.42 & 0.43 & 0.41 & 0.026 & $* * *$ & ns & $\mathrm{ns}$ \\
\hline P excretion, g/day & 0.55 & 0.26 & 0.21 & 0.20 & 0.016 & $* * *$ & $*$ & ns \\
\hline $\mathrm{P}$ retention per intake, $\%$ & 31.4 & 38.5 & 51.2 & 51.1 & 1.19 & $* * *$ & $* * *$ & ns \\
\hline
\end{tabular}

Significance: ns non-significant, o $\mathrm{P}<0.10$, * $\mathrm{P}<0.05$, ** $\mathrm{P}<0.01$ and $* * * \mathrm{P}<0.001$.

Contrasts: C1: Basal diet supplemented with dicalciumphosphate (1) vs. other treatments (2,3 and 4), C2: basal diet without inorganic P (2) vs. phytase supplementations (3 and 4), C3: Aspergillus phytase (3) vs. Trichoderma phytase (4).

$\mathrm{SEM}=$ standard error of means.

creased from 27.0 to $58.0 \%$ and 34.8 to $40.9 \%$, respectively. It would appear that the effect of phytase supplementation is partly feed ingredient dependent, being higher in feeds of high phytate $\mathrm{P}$ and low intrinsic phytase content, such as maize and soybean meal. Utilisation of phytate $\mathrm{P}$ is also influenced by the dietary Ca:total Pratio as increases in this ratio has linearly decreased the effect of phytase on $\mathrm{P}$ retention (Schöner et al. 1993, Sebastian et al. 1996a, Qian et al. 1997). According to Sebastian et al. (1996a) optimal responses to microbial phytase are achieved at low dietary $\mathrm{Ca}$ concentrations $(0.6 \%)$. In the present study, dietary Ca content was above the recommended optimal levels, which may have influenced the magnitude of observed responses. However, the Ca contents were similar between treatments and had no influence on the relative differences between phytase supplements.

Microbial phytase supplementations also increased $\mathrm{Ca}$ and ash retention per unit intake $(\mathrm{P}<0.001)$ and decreased $\mathrm{Ca}$ excretion $(\mathrm{P}<0.05)$ compared to the negative control, a finding in agreement with the studies of Schöner et al. (1993), Kiiskinen et al. (1994), Yi et al. (1996) and Kornegay et al. (1996). Improvement in Ca utilisation was expected, since phytase liberates $\mathrm{Ca}$ from the Ca-phytate complex and the availability of $\mathrm{P}$ increases with availability of $\mathrm{Ca}$ (Sebastian et al. 1996b).

Nitrogen retention per unit intake also slightly increased with phytase supplementation $(\mathrm{P}<0.05)$. Similarly, $\mathrm{N}$ retention of maize-soybean meal diet has also been shown to be improved by increasing phytase addition in previous studies (Schöner et al. 1993, Sebastian et al. 1996b, Yi et al. 1996). Phytase supplementation may also release phytate-bound protein and amino acids for absorption and utilisation and thereby improve $\mathrm{N}$ retention (Ravindran et al. 1999).

Both Trichoderma and Aspergillus phytases improved $(\mathrm{P}<0.05)$ apparent ileal digestibility of $\mathrm{P}$ in maize-soybean meal diets compared to the negative control treatment (Table 3). There is limited information available concerning the ef- 


\section{AGRICULTURAL AND FOOD SCIENCE IN FINLAND}

Valaja, J. et al. Effect of two microbial phytases on P utilisation in broilers

Table 3. Effect of microbial phytases supplementations on apparent ileal nutrient digestibility in broilers fed maize-soybean meal based diet.

\begin{tabular}{|c|c|c|c|c|c|c|c|c|}
\hline Treatment & 1 & 2 & 3 & 4 & SEM & \multicolumn{3}{|c|}{ Significance } \\
\hline Dicalcium phosphate & + & - & - & - & & $\mathrm{C} 1$ & $\mathrm{C} 2$ & $\mathrm{C} 3$ \\
\hline Phytase & - & - & Aspergillus & Trichoderma & & & & \\
\hline $\mathrm{n}$ & 6 & 6 & 6 & 6 & & & & \\
\hline Dry matter & 78.7 & 82.2 & 82.4 & 81.4 & 0.40 & $* * *$ & ns & $\mathrm{o}$ \\
\hline Organic matter & 80.1 & 83.3 & 83.5 & 82.6 & 0.40 & $* * *$ & ns & ns \\
\hline Ash & 52.8 & 59.2 & 60.2 & 56.5 & 1.11 & $* *$ & ns & $*$ \\
\hline Nitrogen & 75.8 & 79.5 & 79.9 & 78.6 & 0.45 & $* * *$ & ns & $*$ \\
\hline Calcium & 45.2 & 59.7 & 57.5 & 46.6 & 1.74 & $* * *$ & $* *$ & $* * *$ \\
\hline Phosphorus & 59.8 & 56.3 & 63.7 & 59.5 & 1.77 & ns & $*$ & ns \\
\hline
\end{tabular}

Significance: ns non-significant, o $\mathrm{P}<0.10$, $* \mathrm{P}<0.05$, ** $\mathrm{P}<0.01$ and $* * * \mathrm{P}<0.001$.

Contrasts: $\mathrm{C} 1$ : Basal diet supplemented with dicalciumphosphate (1) vs. other treatments (2,3 and 4), C2: basal diet without inorganic P (2) vs. phytase supplementations (3 and 4), C3: Aspergillus phytase (3) vs. Trichoderma phytase (4).

$\mathrm{SEM}=$ standard error of means.

fects of microbial phytase on apparent ileal $\mathrm{P}$ digestibility. In the study of Ravindran et al. (2000) phytase supplementation increased apparent ileal P digestibility of wheat-sorgum-soybean meal diet up to $30.3 \%$-units, the improvement being clearly greater than that in the current study. However, the apparent ileal $\mathrm{P}$ digestibility of control diets was lower than that in our study (42.2 vs. $56.3 \%$ ), which probably arised due to differences in basal diet ingredients. In pigs, phytase supplementation effectively enhanced apparent ileal $\mathrm{P}$ digestibility in maize and soybean meal based diets (Jongbloed et al. 1992, Mroz et al. 1994). Apparent ileal digestibility of Ca was lowest for the positive control diet that was supplemented with inorganic $\mathrm{P}(\mathrm{P}<0.001)$. In contrast to nutrient retention, phytase supplementations decreased apparent ileal digestibility of $\mathrm{Ca}$ relative to the negative control treatment $(\mathrm{P}<0.01)$.

Apparent ileal digestibility of dry matter $(\mathrm{P}<0.001)$, organic matter $(\mathrm{P}<0.001), \mathrm{N}$ $(\mathrm{P}<0.001)$ and ash $(\mathrm{P}<0.01)$ were lower for the positive control diet compared to other treatments. Phytase supplementation had no effect on the apparent ileal digestibility of organic matter, $\mathrm{N}$ or ash. The current findings are consistent with previous studies demonstrating that phytase has no effect (Sebastian et al. 1997) or elicits only minor improvements (Namkung and Leeson 1999) on apparent ileal $\mathrm{N}$ digestibility of maize-soybean meal based diets. In contrast, Ravindran et al. (1999) observed that phytase supplementation improved apparent ileal digestibility of $\mathrm{N}$ by 3.1 and $4.8 \%$-units in maize and soybean meal, respectively, and the apparent ileal $\mathrm{N}$ and amino acid digestibility responses to phytase appeared to be negatively related to the inherent $\mathrm{N}$ digestibility of dietary ingredient. Furthermore, phytase additions improved apparent ileal $\mathrm{N}$ digestibility of wheat-sorgum-soybean meal diets between 1.6 and $4.7 \%$-units (Ravindran et al. 2000).

Both Aspergillus niger and Trichoderma reesei phytases were equally effective in improving $\mathrm{P}$ and $\mathrm{Ca}$ utilisation and decreasing $\mathrm{P}$ excretion (Table 2). No differences in apparent ileal digestibity of $\mathrm{P}$ were indentified between the two phytase sources (Table 3). Apparent ileal digestibility of $\mathrm{Ca}(\mathrm{P}<0.001), \mathrm{N}(\mathrm{P}<0.05)$ and ash $(\mathrm{P}<0.05)$ were lower for the Trichoderma than the Aspergillus phytase supplemented diet. However, $\mathrm{N}$ retention per unit intake tended $(\mathrm{P}<0.10)$ to be higher for diets supplemented with Trichoderma than Aspergillus phytases. In other respect, no differences were observed between 


\title{
AGRICULTURAL AND FOOD SCIENCE IN FINLAND
}

\author{
Vol. 10 (2001): 19-26.
}

the two phytases. Phytase supplementations from various sources have generally been equally effective in enhancing $\mathrm{P}$ utilisation (Kiiskinen et al. 1994, Broz et al. 1994, Kornegay et al. 1996, Yi et al. 1996). Responses to phytase supplements are dose-dependent, since the release of $\mathrm{P}$ per unit phytase decreases as the amount of phytase per unit diet increases (Kornegay et al. 1996). Nelson et al. (1968) reported that different cultures of Aspergillus derived phytases had variable effects on $\mathrm{P}$ utilisation, with the highest response with Aspergillus niger. However, absolute phytase activities of different supplements were not determined. Use of both Aspergillus niger and Trichoderma reesei phytase supplementations of maize-soybean meal based diets in pigs have been shown to improve similarly phytate-P availability (Näsi et al. 1999).

In conclusion, both Aspergillus niger and Trichoderma reesei phytases were equally effective in improving utilisation of plant $\mathrm{P}$ in maizesoybean meal based diet in broiler chickens. However, phytase supplements had only minor effects on the digestibility and utilisation of other nutrients.

Acknowledgements. Authors gratefully acknowledge Ms Ritva Muotila, Ms Kaarina Karppinen and Mr Tapani Ratilainen for technical assistance and care of experimental animals. Laboratory staff of Animal Nutrition are also acknowledged for undertaking the chemical analysis.

\section{References}

AOAC 1990. Official methods of analysis. Association of Official Analytical Chemists. Inc., Arlington, Virginia, $1141 \mathrm{p}$.

Broz, J., Oldale, P., Perrin-Volz, A.-H., Rychen, G., Schulze, J. \& Simoes Nunes, C. 1994. Effects of supplemental phytase on performance and phosphorus utilisation in broiler chickens fed a low phosphorus diet without addition of inorganic phosphate. British Poultry Science 35: 273-280.

Eeckhout, W. \& De Paepe, M. 1994. Total phosphorus, phytate-phosphorus and phytase activity in plant feedstuffs. Animal Feed Science and Technology 47: 19-29.

Jongbloed, A.W., Mroz, Z. \& Kemme, P.A. 1992. The effect of supplementary Aspergillus niger phytase in diets for pigs on concentration and apparent digestibility of dry matter, total phosphorus, and phytic acid in different sections of the alimentary tract. Journal of Animal Science 70: 1159-1168.

Kiiskinen, T., Piiroinen, J. \& Hakonen, T. 1994. Effects of supplemental microbial phytase on performance of broiler chickens. Agricultural Science in Finland 3: 457-466.

Kornegay, E.T., Denbow, D.M., Yi, Z. \& Ravindran, V. 1996. Response of broilers to graded levels of microbial phytase added to maize-soybean-meal-based diets containing three levels of non-phytate phosphorus. British Journal of Nutrition 75: 839-852.

Leske, K.L. \& Coon, C.N. 1999. A bioassay to determine the effect of phytase on phytate phosphorus hydrolysis and total phoshorus retention of feed ingredients as determined with broilers and laying hens. Poultry Science 78: 1151-1157.

Mroz, Z., Jongbloed, A.W. \& Kemme, P.A. 1994. Apparent digestibility and retention of nutrients bound to phytate complexes as influenced by microbial phytase and feeding regimen in pigs. Journal of Animal Science 72: 126-132.

Namkung, H. \& Leeson, S. 1999. Effect of phytase enzyme on dietary nitrogen-corrected apparent metabolizable energy and the ileal digestibility of nitrogen and amino acids in broiler chicks. Poultry Science 78: 1317-1319.

Näsi, M., Partanen, K. \& Piiroinen, J. 1999. Comparison of Aspergillus niger phytase and Trichoderma reesei phytase and acid phosphatase on phytate phosphorus availability in pigs fed on maize-soybean meal or barley-soybean meal diets. Archives of Animal Nutrition 52: 15-27.

Nelson, T.S., Shieh, T.R., Wodzinski, R.J. \& Ware, J.H. 1968. The availability of phytate phosphorus in soybean meal before and after treatment with a mould phytase. Poultry Science 41: 1842-1848.

Piddington, C.A., Houston, C.S., Paloheimo, M., Cantrell, M. Miettinen-Oinonen, A., Nevalainen, H. \& Rambosek, J. 1993. The cloning and sequencing of genes encloning phytase (phy) and $\mathrm{pH}$ 2.5-optimum acid phosphatase (aph) from Aspergillus niger var. awamori. Gene 133: 55-62.

Qian, H., Kornegay, E.T. \& Denbow, D.M. 1997. Utilization of phytate phosphorus and calcium as influenced by microbial phytase, cholecalciferol, and the calcium:total phosphorus ratio in broiler diets. Poultry Science 76: 37-46.

Ravindran, V., Cabahug, S., Ravindran, G. \& Bryden, W.L. 1999. Influence of microbial phytase on apparent ileal amino acid digestibility of feedstuffs for broilers. Poultry Science 78: 699-706.

- , Cabahug, S., Ravindran, G., Selle, P.H. \& Bryden, W.L. 2000. Responses of broiler chickens to micro- 


\title{
AGRICULTURAL AND FOOD SCIENCE IN FINLAND
}

\author{
Valaja, J. et al. Effect of two microbial phytases on P utilisation in broilers
}

bial phytase supplementation as influenced by dietary phytic acid and non-phytate phosphorus levels II. Effects on apparent metabolisable energy, nutrient digestibility and nutrient retention. British Poultry Science 41: 193-200.

SAS 1990. SAS / STAT Users Guide Version 6. 4th Ed. SAS Institute Inc., Cary, NS. 1686 p.

Schöner, F.-J., Hoppe, P.P., Schwarz, G. \& Wiesche, H. 1993. Vergleich von microbieller Phytase und anorganischem Phosphat bei Masthahnenküken: Wirkungen auf die Mastleistungen und die Mineralstoffretention bei variierter Calcium-Versorgung. Journal of Animal Physiology and Animal Nutrition 69: 235-244.

Sebastian, S., Touchburn, S.P., Chavez, E.R. \& Lague, P.C. 1996a. Efficacy of supplemental microbial phytase at different dietary calcium levels on growth performance and mineral utilization of broiler chickens. Poultry Science 75: 1516-1523.

- , Touchburn, S.P., Chavez, E.R. \& Lague, P.C. 1996b. The effects of supplemental microbial phytase on the performance and utilization of dietary calcium, phosphorus, copper, and zinc in broiler chickens fed cornsoybean diets. Poultry Science 75: 729-736.

-, Touchburn, S.P., Chavez, E.R. \& Lague, P.C. 1997.
Apparent digestibility of protein and amino acids in broiler chickens fed a corn-soybean diet supplemented with microbial phytase. Poultry Science 76: 17601769.

Simons, P.C.M., Versteegh, H.A.J., Jongbloed, A.W., Kemme, P.A., Slump, P., Bos, K.D., Wolters, M.G.E. Beudeker, R.F. \& Vershoor, G.J. 1990. Improvement of phosphorus availability by microbial phytase in broilers and pigs. British Journal of Nutrition 64: 525540 .

Tayssky, H.H. \& Shorr, E. 1953. A microcolorimetric method for the determination of inorganic phosphorus. Journal of Biological Chemistry 202: 675-685.

Tuori, M., Kaustell, K., Valaja, J., Aimonen, E., Saarisalo, E. \& Huhtanen, P. 1995. Rehutaulukot ja ruokintasuositukset. Märehtijät - siat - siipikarja - turkiseläimet - hevoset. Yliopistopaino, Helsinki 1995. 99 p. ISBN 951-46-6971-7.

Yi, Z., Kornegay, E.T., Ravindran, V. \& Denbow, D.M. 1996. Improving phytate phosphorus availability in corn and soybean meal for broilers using microbial phytase and calculation of phosphorus equivalency values for phytase. Poultry Science 75: 240-249.

\section{SELOSTUS}

\section{Fytaasientsyymilisäyksen vaikutus fosforin hyväksikäyttöön maissi-soijarouhepohjaisessa broilerrehussa}

\author{
Jarmo Valaja, Sini Perttilä, Kirsi Partanen, Tuomo Kiiskinen ja Jari Piironen \\ Maatalouden tutkimuskeskus ja Röhm Enzyme Finland Oy
}

Sulavuus- ja tasekokeessa selvitettiin kahden erilaisen fytaasientsyymilisäyksen vaikutuksia maissi-soijarouherehuseosta saaneiden broilereiden fosforin hyväksikäyttöön ja eritykseen. Tutkittavat fytaasientsyymivalmisteet, FINASE ${ }^{\circledR}$ FP-500 ja FINASE ${ }^{\circledR}$ P, oli tuotettu kahdella erilaisella mikrobikannalla, Aspergillus nigerillä tai Trichoderma reeseillä. Kokeessa oli 96 broilerpoikasta, joiden ikä kokeen alussa oli 21 ja lopussa 37 vuorokautta. Broilereita pidettiin kolmikerroksisessa häkkipatterissa neljän eläimen häkeissä. Rakeistetun koerehun pääasiallisina raakaaineina olivat maissi ja soijarouhe. Koekäsittelyjä oli neljä: positiivinen vertailu, jossa dikalsiumfosfaattitäydennys, negatiivinen vertailu ilman epäorgaanista fosforitäydennystä sekä kaksi rehua ilman epäor- gaanista fosforia, joihin oli lisätty joko Aspergillus tai Trichoderma pohjaista fytaasientsyymiä.

Molemmat fytaasientsyymilisäykset paransivat selvästi maissi-soijarouhe-rehun fosforin käyttökelpoisuutta ja vähensivät ulosteissa erittyvän fosforin määrää. Kasvifosforin hyväksikäyttö parani 38,5 $\%$ :sta $51,1 \%$ :iin verrattuna rehuun, joka ei sisältänyt epäorgaanista fosforia tai fytaasientsyymiä. Myös fosforin ohutsuolisulavuus parantui fytaasientsyymin vaikutuksesta. Sekä Aspergillus että Trichoderma fytaasin vaikutukset fosforin hyväksikäyttöön olivat samanlaiset. Fytaasientsyymi paransi myös rehun kalsiumin hyväksikäyttöä, mutta vaikutukset muiden ravintoaineiden hyväksikäyttöön tai sulavuuteen olivat vähäisiä. 